\title{
LOCALIZATION FACTORS AND DEVELOPMENT STRATEGIES FOR PRODUCER SERVICES: A CASE STUDY OF BELGRADE, SERBIA
}

Vera Gligorijević, Mirjana Devedžić, Ivan Ratkaj

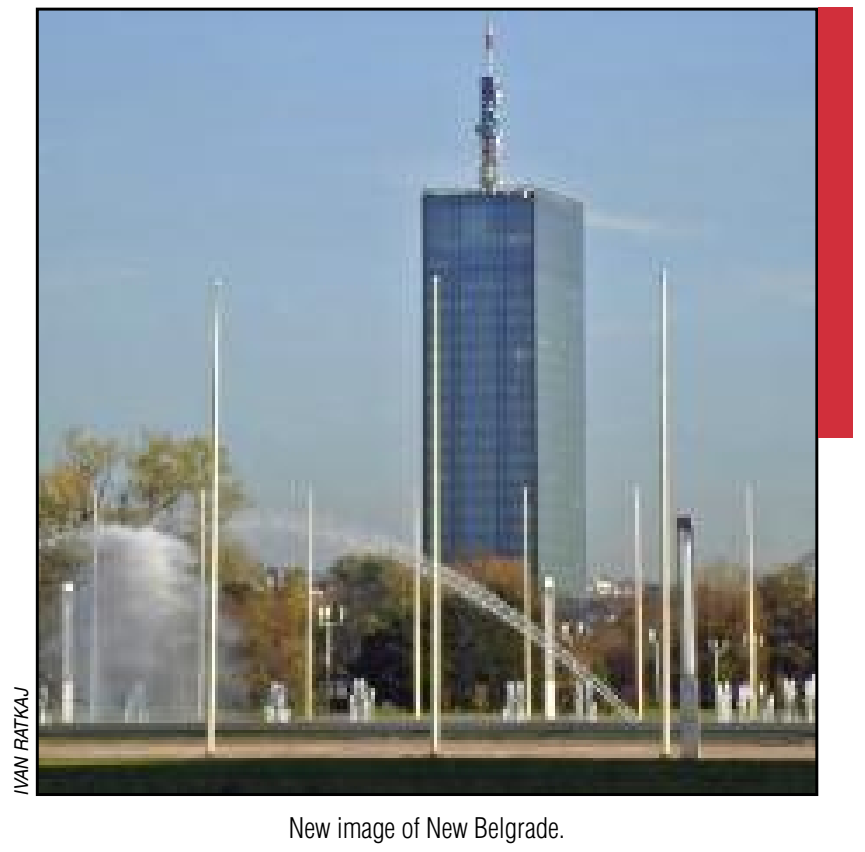




\section{Localization factors and development strategies for producer services: a case study of Belgrade, Serbia}

DOI: http://dx.doi.org/10.3986/AGS54109

UDC: 911.375:336(497.11Beograd)

711.552(497.11Beograd)

COBISS: 1.01

ABSTRACT: This article highlights the patterns of Advanced Producer Services (APS) in Belgrade and relates them to contemporary spatial and economic intrametropolitan transformations. The locational strategies of APS have influenced the creation of another center called New Belgrade next to the traditional central business district (CBD). Over the last ten years, government planning documents and the location preferences of foreign firms have made New Belgrade the most attractive business location in Serbia. In a sample of the leading APS firms in Belgrade, 129 firms are analyzed in terms of firm sector, ownership, and location. The results confirm the multipolar-monocentric pattern, which appears to be a common feature in many European cities.

KEY WORDS: advanced producer services, location strategy, polycentrism, world city networks, Belgrade, Serbia

The article was submitted for publication on February 23, 2013.

ADDRESSES:

Vera Gligorijević, Ph. D.

Faculty of Geography, University of Belgrade

Studentski trg 3/3, 11000, Belgrade, Serbia

E-mail: vera.gligorijevic@gmail.com

Mirjana Devedžić, Ph. D.

Faculty of Geography, University of Belgrade

Studentski trg 3/3,11000, Belgrade, Serbia

E-mail: mdevedzic@gmail.com

Ivan Ratkaj, Ph. D.

Faculty of Geography, University of Belgrade Studentski trg 3/3,11000, Belgrade, Serbia

E-mail: ivanratkaj@sbb.rs 


\section{Introduction}

Advanced Producer Services (APS) are the key agents of cities and the economy (Stein 2002; Basens et al. 2010; Taylor et al. 2009; Lundquist, Oland and Henning 2008) as well as a standard unit of measurement for inclusion in the global network in the context of theories on global cities (Sassen 1991; Castells 1996; Taylor 2004). The increase in the significance of cities as centers of economic flows raises the question of whether it is possible for cities located in less-developed countries, such as Belgrade, to take a much higher position in the world city hierarchy compared to the countries they are located in. Here it is important to note Sassen's (2001) observation that the position on the world city scale depends on the economy, which is not necessarily national, which makes these cities independent of the national economic policy. This is where the opportunity for cities like Belgrade can be seen, because in the global cities theory capitals of post-communist countries are considered to be the most important actors in integrating national territories into global flows (Musil 1993).

Concerning APS and urban organization and structure, Hall $(2001,2004)$ states that today the traditional CBD is of greatest importance to the location of banks and financial institutions. However, it is also being supplemented by secondary business districts and other nodes. According to Hall (2001), previously established businesses remain inside the $\mathrm{CBD}$, which is not the case with new companies. As the literature suggests, the internal spatial structure changes in two ways: the creation of polycentric metropolitan urban forms (Taylor, Evans and Pain 2006; Hall and Pain 2006) or development of a multipolar-monocentric urban structure (Bourdeau-Lepage and Huriot 2005; Halbert 2004). In most European cities, the last thirty years have witnessed the rise and frequently the externalization of high-order activities (producer services, financial services, headquarters of large firms) devoted to economic design, decision, and control, or more generally to economic coordination (Bourdeau-Lepage and Huriot 2005).

Geographical research on producer services has focused on three issues: regional location patterns, exportability of services, and the intrametropolitan location of service activities (Coffey 1995).

For the UK, Daniels (1995) found some intra-regional redistribution from large cities to adjacent towns, but the interregional pattern of producer services in Britain continues to be dominated by the southeast. Apart from deconcentration, a trend of increasing interregional and interurban specialization of APS can be observed. Examples of this are financial services in London, services auxiliary to a »control economy « in Paris, textile-engineering consulting in Lille-Roubaix-Tourcoing, services related to high-tech firms in Rhône-Alpes and southern France, engineering and software in Munich, accounting and consulting in Frankfurt, advertising in Hamburg and Düsseldorf, certification of ships in Oslo, environmental services in Copenhagen, »specialized « production areas in Portugal, and specialized engineering and management consulting in a variety of northern Italian cities and cities in Emilia Romagna (Mouleart and Todtling 1995).

The multipolar urban location pattern partly has to do with the appearance of new actors such as international firms, developers, and institutional investors promoting new tertiary centers, and partly with a decline in the attractiveness of central city locations. The Paris region (Île-de-France) shows an internal multipolarity and a displacement of part of the economic power towards the periphery (Halbert 2007; Shearmur and Alvergne 2002). However, despite the relative dispersal of service activities towards the west and southwest of the first and second couronne, control activities have not left Paris intramuros (Moualert and Gallouj 1995). A similar process of intra-urban and intra-regional dispersal can be identified for London and southeast England (Pratt 2008), the large German agglomerations (Schamp 1995; Luthi, Thierstein and Goebel 2010) and the Vienna region (Todtling and Traxler 1995). In the metropolitan area of Lisbon, in contrast, APS are still strongly concentrated in the city center; so far, suburbanization has been limited to trade and transport activities without APS (Ferrao and Domingues 1995). For the Nordic countries, Illeris and Sjøholt $(1995,218)$ found that "... only a few business services really depend on a central city location for their contacts. Most of the firms that are still located in the center are there for prestige reasons or because they appreciate the environment. However, as car accessibility deteriorates and rents increase in the urban center, they tend to shift to suburban locations."

According to the 2008 report compiled by GaWC regarding well-known city connectivity measures, Belgrade belongs to the high-sufficiency category (GaWC 2008). The GaWC research team developed a new measure of the dynamics of contemporary cities devised by the GaWC research network. Unfortunately (according to Global Buzz-The GaWC Monthly Monitor, table 2010-07), Belgrade cannot be found among the sixty-two cities studied (GaWC, 2010). Of all the cities in transition, Moscow holds the best position, and apart from Moscow the analysis includes Budapest and Warsaw. 


\section{Methodology}

In order to study the patterns of business activity in Belgrade metropolitan areas, we used descriptive case-study research. For this article it was important to select cases at three different levels: territorial selection, APS sector selection, and APS firm selection. The territorial selection of the Belgrade metropolitan area comes down to spatial zoning, where two city centers have been named: the wider CBD (the traditional zone of the work function agglomeration) and New Belgrade (the municipality that has been experiencing the most intensive business development since the beginning of the 1990s). The rest of the urban area is not characterized by marked growth of work function and is generally a zone of dispersed locations of companies. The CBD has been statistically precisely defined combining geographical regression of work function and spatial clustering methods (Ratkaj 2009). In addition, we distinguish the »wider $\mathrm{CBD}$, « a statistically defined CBD expanded using Euclid's distance (buffering) of $500 \mathrm{~m}$. The aim was to indicate the existence of APS firms that gravitate towards the CBD as those located within walking distance from the CBD. In this context, the wider CBD can be viewed as a functional CBD with more flexible borders.

APS encompass seven sectors: advertising, finance and banking, insurance, information technology (IT), law, consulting, and accounting. Consulting incorporates several subsectors: management consulting, business consulting, design consulting, and human resource consulting. The selection of the sectors was performed in compliance with the analysis of polycentric European regions (Taylor, Evans and Pain 2006). The same APS sectors form the basis of the interlocking network model developed by a team of Globalization and World Cities Research Network (GaWC) researchers for studying the world city network (Taylor et al. 2009).

The selection of APS firms was performed according to their rank. The sample included the best companies per sector ranked according to income in 2009. The availability of the data caused the samples to be unevenly distributed among sectors (Table 1). The literature suggests a sample that only consists of APS transnational corporations (TNCs). However, Belgrade's meager APS TNC sample was not enough to provide solid arguments. Therefore the sample included all foreign firms. The authors suggest that it is possible to equate foreign companies with TNCs. This supposition has been confirmed by the results of the analysis of the location of foreign APS firms in Belgrade that have the same location patterns as APS TNCs in global cities (Han and Qin 2009; Taylor et al. 2009; Hermelin 2007; Shearmur and Alvergne 2002).

\subsection{Data sources}

All of the data were gathered from secondary sources, such as various databases, census statistics, and Serbian Business Registers Agency databases. In order to identify APS firms in Belgrade, we used a two-step procedure. The first step consisted of identifying the most successful APS firms doing business in Belgrade, for which we used special publications from The Economist; in particular, Top 300 (2009) for IT firms, and Banks and Insurance Companies (2009) for finance/banking, insurance and accounting firms. We also used Taboo magazine and its review »Results of Business Activities of Marketing Communication Agencies« (2009) for advertising firms, then Chambers et al. (Chambers ... 2014) for law firms, Gartner Special Reports Top 10 Consulting Services Companies for South-East Europe (Internet 1), and the Belgrade Chamber of Commerce register of consulting agencies (Internet 2).

Table 1: Number of firms by sectors and capital.

\begin{tabular}{lccc}
\hline Sectors & Number of firms & Domestic & Foreign \\
\hline Advertising & 24 & 20 & 4 \\
Finance and Banking & 21 & 6 & 15 \\
Insurance & 12 & 6 & 6 \\
IT & 7 & 2 & 5 \\
Law & 19 & 12 & 7 \\
Consultancy & 28 & 16 & 12 \\
Accountancy & 18 & 14 & 4 \\
\hline TOTAL & 129 & 76 & 53 \\
\hline
\end{tabular}


The second step consisted of checking the data for each of the firms in the Serbian Business Registers Agency national database (Internet 3). This database represents the official statistics of all firms and organizations in Serbia. It provided information on firms, including type of business activity in compliance with NACE Rev. 2 codes, current status (active or inactive), prevailing capital origin (domestic or foreign), and location (address).

\section{Results}

The findings suggest that the distribution pattern of producer services has gradually changed from dispersed to centripetal development towards the new business district. This article defines three aspects for distinguishing and analyzing APS firms: area, capital origin, and sector.

\subsection{The CBD versus New Belgrade}

Table 2 summarizes the data and relates them to the territorial division of the Belgrade metropolitan area. Of the total number of APS firms, 53\% are located in the wider CBD. All sectors are present there except IT firms, which prefer New Belgrade or other areas. Consulting, law, and advertising firms are present in the greatest numbers, whereas there are only a small number of banks and insurance companies. Approximately $70 \%$ of the firms in the CBD were founded using domestic capital (Figure 1).

Table 2: Share of sectors in the CBD and New Belgrade.

\begin{tabular}{lcccccccc}
\hline & Advertising & $\begin{array}{c}\text { Finance } \\
\text { and Banking }\end{array}$ & Insurance & IT & Law & Consultancy & Accountancy & Total \\
\hline CBD & 20,3 & 15,9 & 7,2 & - & 20,9 & 20,3 & 15,9 & 100 \\
New Belgrade & 9,1 & 30,3 & 21,2 & 15,1 & 3,1 & 18,2 & 3,1 & 100 \\
\hline
\end{tabular}

Approximately $26 \%$ of the total number of APS firms analyzed are located in New Belgrade. The rest of the APS firms studied (around 20\%) are dispersed outside the CBD area and New Belgrade and were not considered further. New Belgrade has all seven APS firm sectors presented, with a clear predominance of banks, insurance, consulting, and IT companies. Law firms and accounting companies are fewest in number. Over $80 \%$ of APS firms located in New Belgrade are foreign, and less than $20 \%$ were founded using domestic capital.

\subsection{Domestic versus foreign firms}

Table 3 shows how business is distributed across the Belgrade metropolitan area in terms of whether firms are domestic or foreign. Domestic firms (founded by domestic capital) make up about $60 \%$ of the total number of APS firms in Belgrade. The structure of firms according to capital is uneven in the areas and sectors considered. In the CBD and the rest of the city areas outside New Belgrade, domestic firms are dominant, whereas foreign firms clearly dominate in New Belgrade.

Table 3: Share of domestic and foreign firms in the CBD and New Belgrade.

\begin{tabular}{lcccc}
\hline & The number of APS firms & Foreign firms & Domestic firms & Total \\
\hline CBD & 69 & 30,4 & 69,6 & 100 \\
New Belgrade & 33 & 81,8 & 18,2 & 100 \\
Other & 27 & 18,5 & 81,5 & 100 \\
\hline
\end{tabular}

Territorial distribution of domestic firms is characterized by concentration: almost $90 \%$ of domestic firms are located within the CBD areas, and only $10 \%$ in New Belgrade. Foreign companies (where more than $50 \%$ of the initial capital originates from abroad) are distributed in a polycentric manner: they 
can be found in both areas, but a little more than half of them are located in New Belgrade. In terms of sectors, foreign capital is the major capital in more than $70 \%$ of the firms dealing with banking and information technologies, half the insurance companies, and more than $40 \%$ of consulting companies. Domestic firms make up more than $80 \%$ of the total number of marketing and accounting firms, as well as more than $50 \%$ of the total number of consulting and law firms.

\subsection{Sectors}

APS are divided into seven sectors, represented by a different number of firms (Table 1). However, the sample composition according to the ownership and locational strategy of the firms sampled is far more important than their number. The results are presented for each sector separately (Figure 1).

Advertising: twenty-four firms were analyzed, only four of which have foreign capital as predominant. They are territorially concentrated: $83 \%$ of advertising firms are located inside the CBD. For most of the marketing agencies, accessibility is top priority, which corresponds to the central city zone. The second strategy is locating the firm in relatively distant but highly prestigious zones, set outside the main public transport routes. New Belgrade did not prove to be an attractive location.

Finance and banking: twenty-one firms were analyzed, fifteen of which have foreign capital as predominant. Banks are characterized by polycentric distribution: they are almost evenly distributed among the CBD and New Belgrade. Two locational strategies were identified: location in the city center due to the importance of being accessible and centrally positioned, as well as location in New Belgrade due to the existence of open space suitable for the construction of new large buildings. However, even in New Belgrade, banks are located along main radial roads, which provide a quick link to the city center. In addition, they are located near densely populated New Belgrade areas. Out of ten banks located in New Belgrade, nine have foreign capital as predominant.

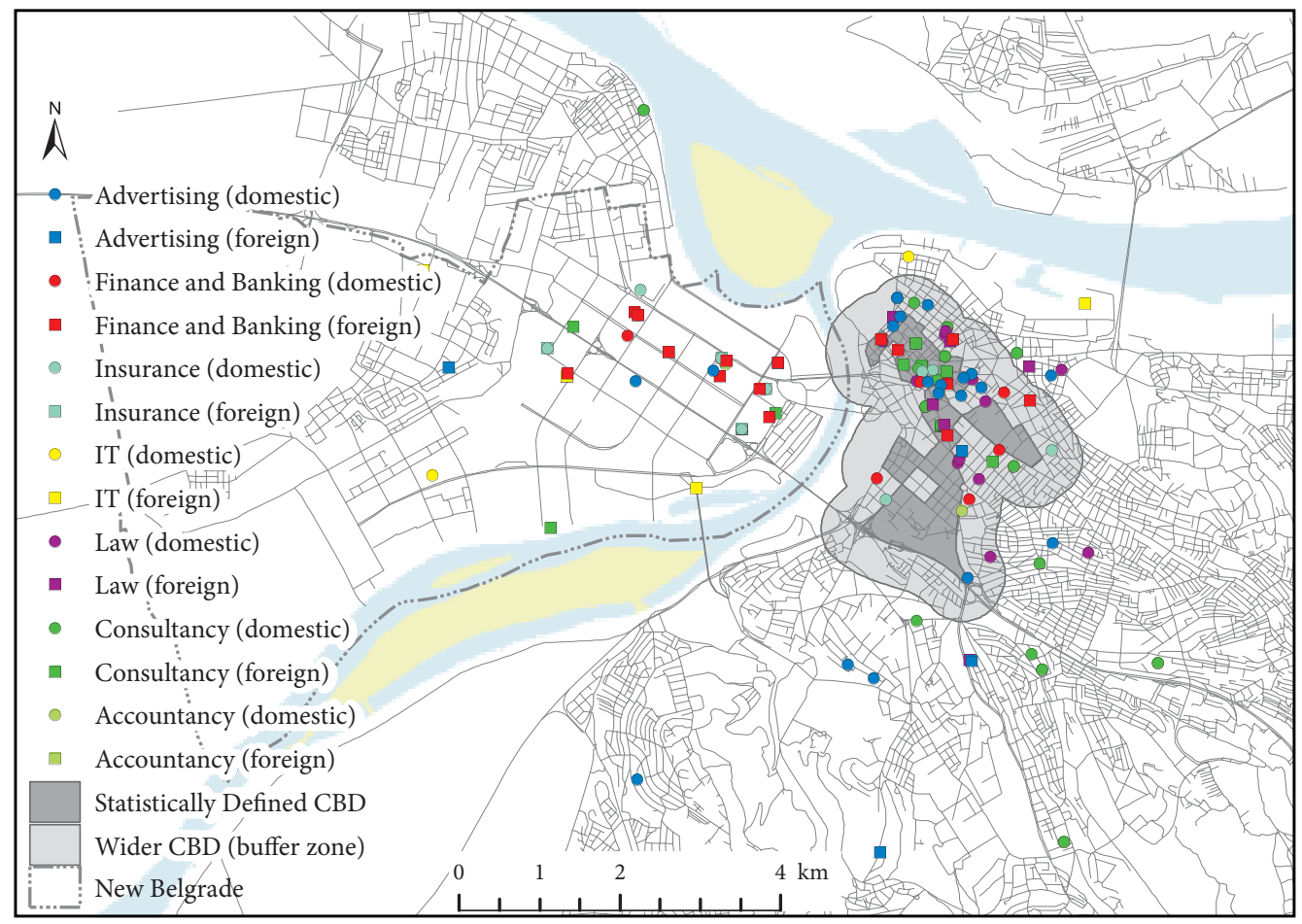

Figure 1: Location choices of firms, by sector and ownership. 


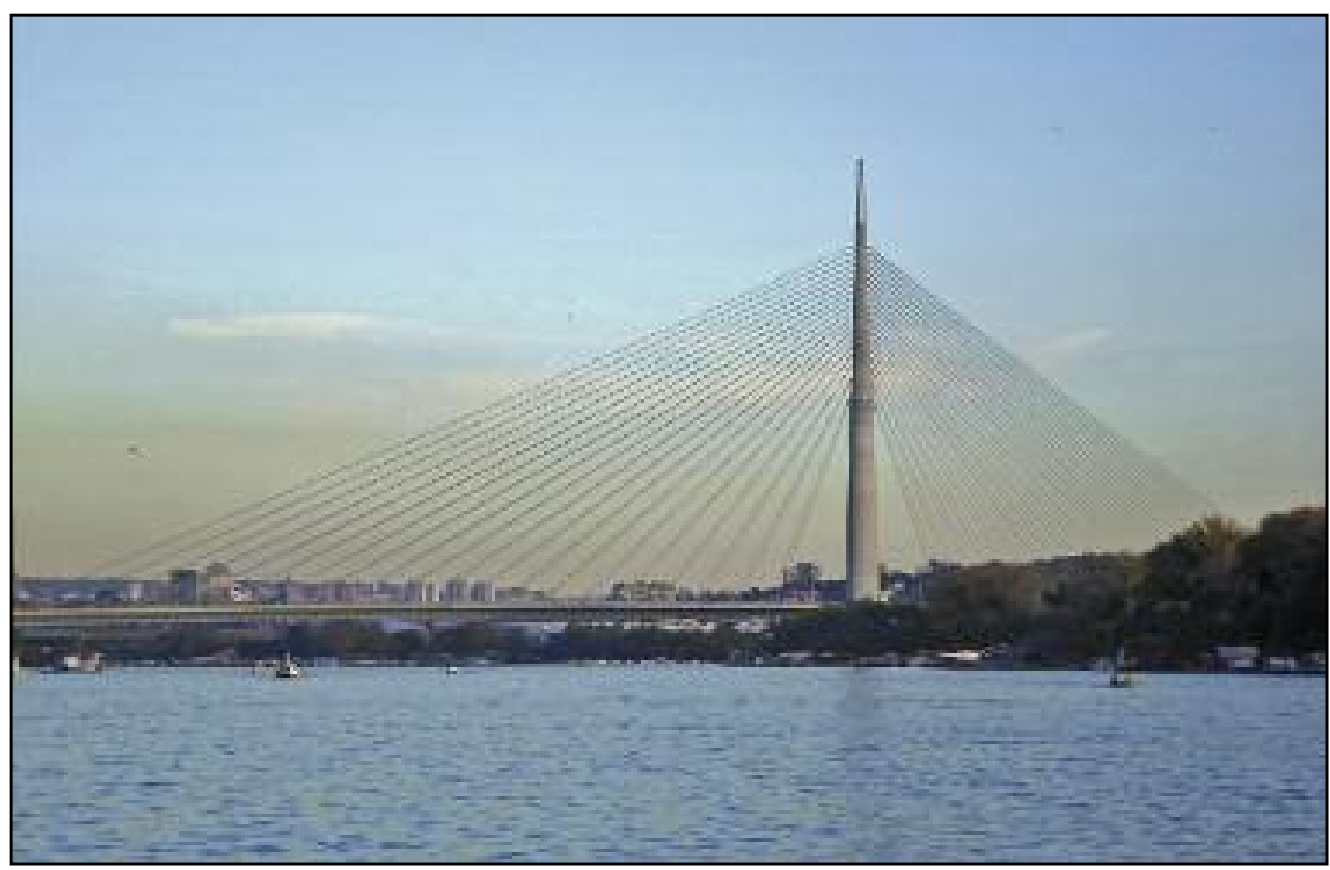

Figure 2: New bridge on the Sava River.

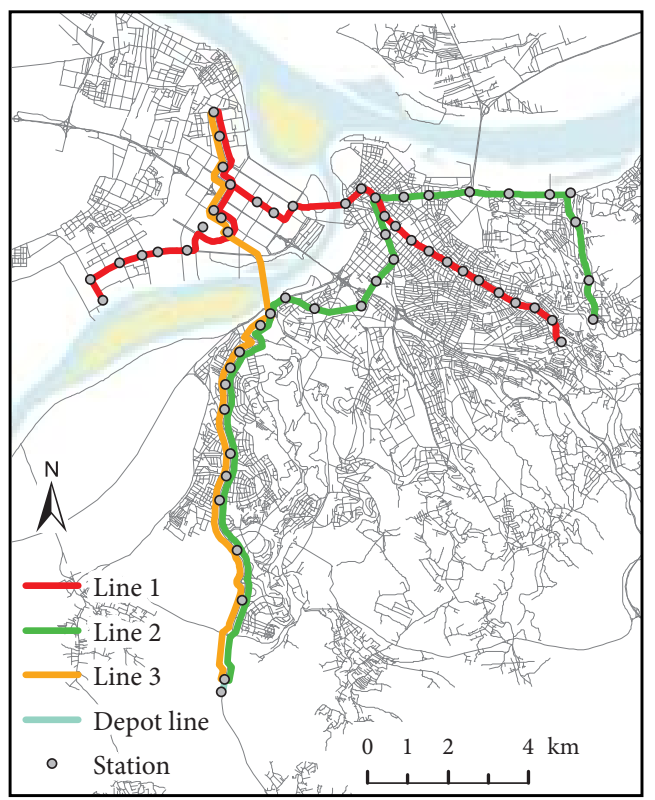

Figure 3: Belgrade subway plan - not yet under construction.

Insurance: twelve firms were analyzed, six of which have foreign capital as predominant. They are located in New Belgrade, with seven of them (six foreign) located in the CBD or zones gravitating towards it as well. The locational strategy is similar to the one the banks have, and foreign companies find New Belgrade especially attractive. Transport accessibility is also important. 
IT: Seven firms were analyzed, five of which have foreign capital as predominant. They are mostly located in New Belgrade (five firms, four of which are foreign). None of them are located inside the CBD or its immediate vicinity. Four firms are located near the freeway. The two companies located near the harbor are not oriented to the domestic market, and so their ability to reach the local population via thoroughfares is not significant.

Law: nineteen firms were analyzed, seven of which have foreign capital as predominant. Only one (foreign) law firm is located in New Belgrade, whereas fourteen of them are located inside the CBD or a zone gravitating towards it. Centrality - that is, being accessible to the local market - is an extremely important factor for their location. The size of the premises is of no importance.

Consulting: twenty-eight firms were analyzed, twelve of which have foreign capital as predominant. They are mostly located in the CBD or in a zone gravitating towards it. There are only six consulting agencies in New Belgrade, all of which are foreign. Centrality is also important for their location, but foreign companies clearly recognize the attractiveness of New Belgrade.

Accounting: eighteen firms were analyzed. Four of them have foreign capital as predominant and most are located in the CBD or a zone gravitating towards it. Accounting companies can also be found in other city regions (six are located outside the wider CBD and New Belgrade). Unlike consulting companies, all accounting companies are located inside the CBD.

\section{Discussion and conclusion}

First, the high level of concentration of APS at the national level in the Belgrade metropolitan area was affected by several factors: the high-order position inherited from the settlement network of the former Socialist Federal Republic of Yugoslavia (SFRY) and Federal Republic of Yugoslavia (FRY), particularly the position of the capital city; the concentration of human capital; and the concentration of direct foreign investments. Important factors to increase APS in Belgrade were transition towards a market economy and economic globalization, and also strategic government decisions towards a knowledge-based economy, which later caused occupational structure changes (Gligorijević 2009).

The second conclusion of the APS pattern analysis is the high level of concentration in the CBD, similar to other large European cities. Urban amenities certainly play a major role in the preference of high-order functions for the CBD (Todtling, Lehner and Trippl 2006; Tonts and Taylor 2010; Wu 2003), which is closely related to prestige and place symbolism. The analysis by Castells (1989) shows that the CBD has a concentration of APS firms, and that the reasons for this lie in the need for face-to-face contact, a business social milieu with a unique culture, a prestigious location, existing office stock, and available ancillary services.

The third result of the research is recognition of intra-urban multipolar development. In the first phases of APS development in Belgrade, APS firms were concentrated in the CBD, and later on some firms dispersed around it. Findings suggest that the distribution pattern of producer services has gradually changed from dispersed to concentrated in the new business center: New Belgrade. It has fewer amenities than the CBD, but it attracts foreign firms and investments. The traditional CBD is still an important residential zone, with a lack of modern business space, which influenced the business shift towards New Belgrade. The advantages of New Belgrade, in comparison to the CBD, include modern transport infrastructure, vicinity of the airport and the highway, the absence of denationalization issues, and extensive open space.

From a socially relatively uniform »large dormitory « under communism, New Belgrade has transformed into a new business center marked by more prominent social stratification (Petrović 2000). Concentration of business facilities in selected zones of New Belgrade presupposes the influx and concentration of the new service class, for which high-quality residential buildings have been built. Based on interviews conducted with experts from the Institute of Architecture and Urban and Spatial Planning of Serbia, Barlov (2009) discusses »the obsession with business-residential construction « and the domination of »investment urbanism « and greenfield investments, and points out that a rapid urban transformation of New Belgrade is underway, leading to the gradual destruction of the functional city aspirations for the needs of the business interests of the minority.

The development of New Belgrade was also influenced by abandoning the centralized planning system and introducing neoliberal capitalism. These changes led to severe collapse of the monocentric structure 
of communist Belgrade. The urban development of New Belgrade is not a controlled and planned counterpart to the CBD, but an embodiment of the market economy. Urban experts face many challenges, but the biggest of all is to reduce the traffic volume and to improve connectivity between the old and new parts of Belgrade. A temporary solution to this problem is the construction of a new bridge on the Sava River (Figure 2) and designing a subway (Figure 3). In addition, New Belgrade's population increase requires social policy improvements, especially investment in schools and hospitals, regardless of the economic effects of these investments.

\section{Acknowledgment}

This article contains research findings from projects nos. 176017 and 47006, supported by the Serbian Ministry of Education, Science, and Technological Development.

\section{References}

Banks and insurance companies. Special edition, Economist, 2009. Belgrade.

Bassens, D., Derudder, B., Taylor, P. J., Pengfei, N., Hoyler, M., Huang, J., Witlox, F. 2010: World city network integration in the Eurasian realm. Eurasian geography and economics 51-3. DOI: http://dx.doi.org/ 10.2747/1539-7216.51.3.385

Barlov, S. 2009: Transformacija jednog grada - Novi Beograd. Internet: http://pescanik.net/2009/09/transformacija-jednog-grada-\%E2\%80\%93-novi-beograd/ (1.9.2009).

Bourdeau-Lepage, L., Huriot, J. M. 2005: On poles and centers: Cities in the French style. Urban public economic review 3.

Castells, M. 1989: The informational city. Oxford.

Castells, M. 1996: The rise of the network society. Oxford.

Chambers Europe publication. Internet 1: http://www.chambersandpartners.com/Europe/Search/Location/ 185. n (17.2.2012)

Coffey, W. J. 1995: Producer services research in Canada. Professional geographer 47.

Daniels, P. W.1995: The locational geography of advanced producer services firms in the United Kingdom. Progress in planning 43, 2-3. DOI: http://dx.doi.org/10.1016/0305-9006(95)96164-M

Ferrao, J., Dominigues, A. 1995: Portugal: The territorial foundations of a vulnerable tertiarisation process. Progress in planning 43, 2-3. DOI: http://dx.doi.org/10.1016/0305-9006(95)96171-M

GaWC, 2008: The World according to GaWC. Internet: http://www.lboro.ac.uk/gawc/world2008t.htm (1.9.2009).

GaWC, 2008: The GaWC monthly monitor, global buzz. Internet: http://www.lboro.ac.uk/gawc/globalbuzz.html (1.9.2009).

Gligorijevic, V. 2009: Demografska obeležja radne snage u Beogradu početkom XXI veka. Demografija 6. Beograd.

Halbert, L. 2004: The decentralization of intrametropolitan business services in the Paris region: Patterns, interpretation, consequences. Economic geography 80-4. DOI: http://dx.doi.org/10.1111/j.19448287.2004.tb00244.x

Halbert, L. 2007: From sectors to functions: producer services, metropolization and agglomeration forces in the Ile-de-France region. Belgeo 1.

Hall, P., Pain, K. 2006: From metropolis to polyopolis. The polycentric metropolis: learning from mega-city regions in Europe. Sterling.

Hall, P. 2004: Polycentricity: concept and measurement. Polynet discussion paper.

Hall, P. 2001: Global city-regions in the twenty-first century. Global city regions: trends, theory, policy. New York.

Han, S., Qin, B. 2009: The spatial distribution of producer services in Shanghai. Urban Studies 46. DOI: http://dx.doi.org/10.1177/0042098009102133

Hermelin, B. 2007: The urbanization and suburbanization of the service economy: producer services and specialization in Stockholm. Geografiska Annaler B - Human geography 89. DOI: http://dx.doi.org/ 10.1111/j.1468-0467.2007.00260.x 
Illeris, S., Sjohot, P. 1995: The Nordic countries: High quality service in a low density environment. Progress in planning 43, 2-3. DOI: http://dx.doi.org/10.1016/0305-9006(95)96169-R

Internet 1: http://www.deloitte.com/assets/Dcom-Global/Local\%20Assets/Documents/Press/deloitte_ vol2_article3.pdf (27.6.2012).

Internet 2: http://217.24.23.93/Aplikacije.aspx?aplikacija=konsultantskeKuce (2.4.2012).

Internet 3: http://pretraga2.apr.gov.rs/ObjedinjenePretrage/Search/Search (8.4.2012).

Lundquist, K-J., Oland, L-O., Henning, M. 2008: Producer services: growth and roles in long term economic development. The Service Industries Journal 28-4. DOI: http://dx.doi.org/10.1080/02642060801917588

Luthi, S., Thierstein, A., Goebel, V. 2010: Intra-firm and extra-firm linkages in the knowledge economy: the case of the emerging mega-city region of Munich. Global networks 10. DOI: http://dx.doi.org/ 10.1111/j.1471-0374.2010.00277.x

Moulaert, F., Todtling, F. 1995: The role of transnational corporations. Progress in planning 43. DOI: http://dx.doi.org/10.1016/0305-9006(95)96163-L

Moulaert, F., Gallouj, C. 1995: Advanced producer services in the french space economy: Decentralisation at the highest level. Progress in planning 43. DOI: http://dx.doi.org/10.1016/0305-9006(95)96165-N

Musil, J. 1993: Changing urban sistems in post-comunists societies in Central Europe: analysis and prediction. Urban studies 30-6. DOI: http://dx.doi.org/10.1080/00420989320080841

Petrovic, M. 2000: Gradovi u tranziciji: iskustva razvijenih zemalja u poslednjim decenijama 20. veka. Sociologija 42-3.

Pratt, A. 2008: Questioning the relationship between advanced producer services, the cultural industries and global cities. L'économie culturelle et ses territoires. Toulouse.

Ratkaj, I. 2009: Prostorno-funkcionalna organizacija Beograda. Beograd.

Taboo magazine. Review »Results of business activities of marketing communication agencies«, 2012, Beograd.

Sassen, S.1991: The global city: New York, London, Tokio. Princeton.

Sassen, S. 2001: Global cities and global city regions: a comparison. Global city regions: trends, theory, policy. Oxford.

Shearmur, R., Alvergne, C. 2002: Intrametropolitan patterns of high-order business service location: A comparative study of seventeen sectors in Ile-de-France. Urban Studies 39-7. DOI: http://dx.doi.org/10.1080/ 00420980220135536

Schamp, E. W. 1995. The geography of APS in a goods exporting economy: The case of West Germany. Progress in planning 43. DOI: http://dx.doi.org/10.1016/0305-9006(95)96166-O

Stein, R. 2002: Producer services, transaction activities and cities: rethinking occupational category in economic geography. European planning studies 10-6. DOI: http://dx.doi.org/10.1080/0965431022000003780

Szelenyi, I.1996: Cities under socialism - and after. Cities after Socialism: Urban and regional change and conflict in post-socialist countries. Oxford.

Taylor, P. J. 2004: World City Network. London.

Taylor, P. J., Evans, D., Pain, K. 2006: Organization of the polycentric metropolis: corporate structures and networks. The polycentric metropolis: Learning from the mega-city regions in Europe. Sterling.

Taylor, P., Evans, D., Hoyler, M., Derudder, B. and Pain, K. 2009: The UK space economy as practiced by advanced producer service firms: identifying two distinctive polycentric city-regional processes in contemporary Britain. International journal of urban \& regional research 33-3. DOI: http://dx.doi.org/ 10.1111/j.1468-2427.2009.00857.x

Todtling, F., Lehner, P. and Trippl, M. 2006: Innovation in knowledge intensive industries: the nature and geography of knowledge links. European planning studies 14-8. DOI: http://dx.doi.org/10.1080/ 09654310600852365

Todtling, F., Traxler, J. 1995: The changing location of advanced producer services in Austria. Progress in planning 43. DOI: http://dx.doi.org/10.1016/0305-9006(95)96168-Q

Tonts, M., and Taylor, M. 2010: Corporate location, concentration and performance: large company headquarters in the Australian urban system. Urban Studies 47-12. DOI: http://dx.doi.org/10.1177/ 0042098009359029

Top 300, Special edition magazin Econom:east, 2009. Beograd.

Wu, F. 2003: Globalization, place promotion and urban development in shanghai. Journal of urban affairs 1-25. DOI: http://dx.doi.org/10.1111/1467-9906.00005 